\title{
Bromelia karatas and Bromelia pinguin: sources of plant proteases used for obtaining antioxidant hydrolysates from chicken and fish by-products
}

\author{
Martha Guillermina Romero-Garay', Emmanuel Martínez-Montaño 2,3 , Adrián Hernández-Mendoza4, \\ Belinda Vallejo-Cordoba ${ }^{4}$, Aarón Fernando González-Córdova ${ }^{4}$ Efigenia Montalvo-González \\ and María de Lourdes García-Magaña ${ }^{1 *}$
}

\begin{abstract}
In the present study, we evaluated new sources of plant proteases from fruits of Bromelia karatas (BK) and Bromelia pinguin (BP) to obtain antioxidant hydrolyzates/bioactive peptides (BPs) derived from chicken by-products (CH) and fish by-products $(\mathrm{FH})$. The profile of the peptides was identified by reverse-phase high-resolution liquid chromatography (RP-HPLC) and the size weight distribution by molecular exclusion chromatography (SEC). The hydrolysates obtained with BK in both sources of by-products showed greater antioxidant capacity compared to those obtained with BP, presenting similar or higher values when compared to a commercial plant enzyme. The use of new sources of plant proteases allowed to obtain hydrolysates of hydrophilic character with a high percentage $(>50 \%)$ of peptides with molecular weights $<17.5 \mathrm{kDa}$ from chicken and fish by-products. Therefore, based on the results obtained in antioxidant capacity it is possible to consider the hydrolysates as potential ingredients, food additives, and pharmaceutical products.
\end{abstract}

Keywords: Antioxidant capacity, Bioactive peptides, By-products, Hydrolysates, Proteases

\section{Introduction}

Antioxidants are bioactive compounds of vital importance in food processing and human health [1], they can be obtained from different food matrices of plant and animal origin. Free radicals and oxidative stress are involved in the pathogenesis of a wide variety of conditions that include inflammatory diseases, cancer, atherosclerosis, diabetes mellitus, neurodegenerative diseases, HIV/AIDS as well as stimulating premature skin aging $[2,3]$. Up to date, a large number of studies have been published

*Correspondence: mgarciam@ittepic.edu.mx

${ }^{1}$ Laboratorio Integral de Investigación en Alimentos, Tecnológico Nacional de México/Instituto Tecnológico de Tepic, Av. Tecnológico 2595,

Col. Lagos del Country, 63175 Tepic, Nayarit, Mexico

Full list of author information is available at the end of the article about the antioxidant properties of hydrolysates or foodderived peptides [2], which are considered health-promoting biomolecules with medical applications, besides to possess a nutraceutical potential and application in the food industry [4]. BPs are the usual name of short amino acid sequences (AA), which could be generated from the protein hydrolysis obtained from different sources, but mainly of animal origin such as beef, pork, lamb, poultry, duck and various species of marine organisms [5]. The BPs are conformed by chains of 2-30 AA with molecular weights less than $10 \mathrm{kDa}[6,7]$. BPs has a positive impact on the functions or conditions of the body and influences human health [8].

It is important to use proteins of animal origin from different species to obtain BPs $[9,10]$. In the last few years, the interest for the production of these biomolecules 
from by-products such as bird feathers, blood, viscera, skin, among others has increased $[7,11,12]$, which represent a valuable source of protein and other essential nutrients [13]. In vitro studies have evaluated the antioxidant capacity and activity of different hydrolysates/ peptides derived from poultry, chicken and ducks byproducts $[1-3,14-16]$ and fish by-products [17-22].

Enzymatic hydrolysis by the action of different proteases of animal origin (i.e. trypsin and pepsin), microbial (i.e. alcalase and neutrase) and plants (i.e. bromelain and papain), has been the technological process commonly used for the production of hydrolyzates/peptides derived from food $[4,6]$. The proteases of plant origin are relatively limited to the use of bromelain and papain, these proteases have been employed to obtain hydrolysates and bioactive peptides from fish by-products $[17,23,24]$ and blood from livestock animals [23, 24]. In recent years, research on new sources of proteolytic enzymes has been encouraged, as well as their possible applications in industry. The obtaining of new sources of plant proteases is increasing due to their low production costs, relative abundance in some plants and attractive biochemical characteristics [25], such as their stability over a wide range of $\mathrm{pH}$ and temperature [26]. The fruits of Bromelia pinguin "guamara" and Bromelia karatas "cocuixtle" are presented as an alternative to obtaining plant proteases [4, 26-29]. However, little information exists on the application of these sources of proteases in different food matrices to obtain protein hydrolysates. In this regard, the objective of this work is to obtain and characterize peptides with antioxidant capacity from the enzymatic hydrolysis of chicken by-products and fish by-products using new plant sources of proteases from $B$. karatas "cocuixtle" and B. pinguin "guamara."

\section{Materials and methods Reagents}

ABTS (2,2'-azinobis (3-ethyl benzothiazoline-6-sulfonic)), TPTZ (2,4,6-tri (2-pyridyl)-s-triazine), DPPH (2,2-diphenyl-1-picrylhydrazyl), Trolox (6-hydroxy2,5,7,8-tetramethylchroman-2-carboxylic acid), acetonitrile, trifluoroacetic acid was obtained from Sigma Aldrich (St. Louis, MO) and TNBS (2,4,6-trinitrobenzene sulfonic acid) was acquired from Thermo Fisher Scientific.

\section{Organic material}

The fruits of $B$. karatas, $B$. pinguin, chicken by-products (viscera $44.5 \% \mathrm{w} / \mathrm{w}$, heart $44.5 \% \mathrm{w} / \mathrm{w}$ and blood $11 \% \mathrm{w} / \mathrm{w}$ ) and fish by-products Centropomus ssp. (Scales 50\% w/w and skin $50 \% \mathrm{w} / \mathrm{w}$ ) were collected from a local market at Tepic, Nayarit, Mexico. The organic material was packed in polyethylene bags and transported to the integral food research laboratory of the Instituto Tecnológico de Tepic, Nayarit, Mexico. Organic material was frozen at $-80{ }^{\circ} \mathrm{C}$ and then lyophilized. (70020, Labconco Corporation, Kansas City, MI, USA).

\section{Extraction, semi-purification and proteolytic activity of $B$. pinguin (BP) and B. karatas (BK) proteases}

Enzyme extraction and semi-purification of the fruits from B. pinguin and B. karatas was carried out using the methodology used by García-Magaña et al. [30]. The semi-purified enzyme extracts were centrifuged at $6000 \times g$ for $30 \mathrm{~min}$ at $4{ }^{\circ} \mathrm{C}$, the recovered supernatant was lyophilized and then stored for further analysis.

\section{Proteolytic activity}

The proteolytic activity of the semi-purified protease extracts was determined by the methodology described by Natalucci et al. [31] with slight modifications by García-Magaña et al. [30], using egg albumin as a substrate. $1.1 \mathrm{~mL}$ of egg albumin solution $(1 \mathrm{~g} / 100 \mathrm{~mL})$ was mixed with phosphate buffer $(\mathrm{pH} 6.0,12.5 \mathrm{mM}$ of L-cysteine) and $0.1 \mathrm{~mL}$ of protease extract $(2.6 \mathrm{mg}$ of the lyophilized enzyme in $1.5 \mathrm{~mL}$ of buffer) at $37^{\circ} \mathrm{C}$. The reaction was stopped by adding $1.8 \mathrm{~mL}$ of trichloroacetic acid $(50 \mathrm{~g} / \mathrm{L})$. The solution was centrifuged $(14,000 \times \mathrm{g}$ for $10 \mathrm{~min}$ at $4{ }^{\circ} \mathrm{C}$; Hettich, Mikro 200R, Tuttlingen, Germany) and the absorbance of the supernatant was measured at $280 \mathrm{~nm}$ (JENWAY, 6705, Bibby Scientific Limited, OSA, United Kingdom). A calibration curve with tyrosine $(3 \mathrm{M})$ was used to determine the specific activity expressed as tyrosine units (UT), defined as the change in tyrosine concentration $/ \mathrm{mg}$ protein $/ \mathrm{min}$ at $37^{\circ} \mathrm{C}$. Protein concentration was determined by Bradford [32] and expressed in $\mathrm{mg} / \mathrm{mL}$. The specific activity was determined with the following equation:

$$
A_{U\left(37^{\circ} \mathrm{C}\right)}=\left(\frac{\Delta \text { tyrosine concentration }}{\left(\mathrm{t}^{*} V_{\text {enzyme }} * C_{\text {enzyme }}\right)}\right)\left(\frac{V_{\text {reaction }}}{V_{\text {enzyme }}}\right)
$$

where, $\Delta$ tyrosine concentration, is the difference in absorbances obtained between the test sample and the control; $\mathrm{V}_{\text {enzyme }}$, volume of the enzyme solution $(0.1 \mathrm{~mL})$; $\mathrm{t}$, reaction time $(20 \mathrm{~min})$; $\mathrm{V}_{\text {reaction }}$, volume used in the reaction $(3 \mathrm{~mL}) ; \mathrm{C}_{\text {enzyme }}$, enzymatic concentration obtained by the Bradford method.

\section{Protein hydrolysates from chicken $(\mathrm{CH})$ and fish by-products $(\mathrm{FH})$}

The lyophilized chicken and fish by-products were resuspended $(1: 20, \mathrm{w}: \mathrm{v})$ in $0.2 \mathrm{M}$ sodium phosphate buffer $\mathrm{pH}$ 6.5, homogenized for $2 \mathrm{~min}$ and subjected to heat treatment at $100{ }^{\circ} \mathrm{C}$ for $15 \mathrm{~min}$. Subsequently, the protein substrates were individually hydrolyzed with the 
enzymes extracted from $B$. pinguin (BP), B. karatas (BK) and the bromelain (BRO) was used as a control enzyme, adding $1 \mathrm{~mL}$ of enzyme solution $(100 \mu \mathrm{g}$ of lyophilized enzyme $/ \mathrm{mL}$ re-suspended in $0.1 \mathrm{M}$ phosphate buffer, $\mathrm{pH}$ 6.5 containing, $5 \mathrm{mM} \mathrm{L}$-Cysteine) at the conditions of $40{ }^{\circ} \mathrm{C}$ for $30 \mathrm{~min}$ at $\mathrm{pH} 6.5,25^{\circ} \mathrm{C}$ for $4 \mathrm{~h}$ and $\mathrm{pH} 6.5$ and $37^{\circ} \mathrm{C}$ for $4 \mathrm{~h}$ and $\mathrm{pH} 7.0$, respectively. After this time, the samples were immediately heated at $100{ }^{\circ} \mathrm{C}$ for $15 \mathrm{~min}$ to stop the hydrolysis process. The hydrolysates were centrifuged at $14,000 \times g$ at $4{ }^{\circ} \mathrm{C}$ for $10 \mathrm{~min}$ and then filtered with $0.45 \mu \mathrm{m}$ membranes (Millipore, MF-Membrane Filtres HAWP).

\section{Soluble protein content}

The protein content was determined by the Bradford method [32], from a CH/FH solution of $30 \mathrm{mg} / \mathrm{mL}(\mathrm{w} / \mathrm{v})$. $0.1 \mathrm{~mL}$ of hydrolysate solution was placed with $1 \mathrm{~mL}$ of Bradford reagent, allowed to stand for $10 \mathrm{~min}$ in darkness and the absorbance was measured on a UV-VIS spectrophotometer at $595 \mathrm{~nm}$. Bovine serum albumin (BSA) was used as a standard. The results were expressed in $\mathrm{mg} / \mathrm{mL}$.

\section{Yield}

The hydrolysates were frozen at $-80^{\circ} \mathrm{C}$ and then lyophilized. The yield percentage of hydrolysates was calculated by the equation proposed by Chou et al. [2]:

$$
\text { Yield }(\%)=\left(\frac{\text { lyophilized hydrolysates }(\mathrm{g})}{\text { lyophilized by }- \text { product }(\mathrm{g})}\right) * 100
$$

\section{Degree of hydrolysis}

The degree of hydrolysis (DH) was evaluated based on the quantification of the primary free amino groups liberated during hydrolysis by the method proposed by Adler-Nissen [33] modified by Tovar-Pérez et al. [34]. Briefly, we mixed $120 \mu \mathrm{L}$ of hydrolysates, $1 \mathrm{~mL}$ of $0.2 \mathrm{M}$ phosphate buffer at $\mathrm{pH} 8.2$ and $1 \mathrm{~mL}$ solution of $0.1 \%$ 2,4,6-trinitrobenzene sulfonic acid (TNBS). The mixture was allowed to incubate for $60 \mathrm{~min}$ at $50{ }^{\circ} \mathrm{C}$. The reaction was finished by adding $2 \mathrm{~mL}$ of $0.1 \mathrm{~N} \mathrm{HCl}$. The absorbance of the solution was measured at a wavelength of $340 \mathrm{~nm}$. Blank was prepared in the same way. The degree of hydrolysis (\%) was estimated with the following equation:

$$
D H(\%)=\frac{\left(N H_{2 t}-N H_{0}\right)}{\left(N H_{2 m a x}-N H_{0}\right)} \times 100
$$

where: $\mathrm{NH}_{2 t}=$ concentration of free amino groups after hydrolysis with $B$. pinguin, B. karatas, and bromelain. $\mathrm{NH}_{0}=$ concentration of free amino groups of chicken and fish by-products (without hydrolyzing). $\mathrm{NH}_{2 \max }=$ concentration of free amino groups after total hydrolysis, which was estimated by hydrolysis with $6 \mathrm{~N} \mathrm{HCl}$ at $100{ }^{\circ} \mathrm{C}$ for $24 \mathrm{~h}$. The concentration of free amino groups $\left(\mathrm{NH}_{2}\right)$ was expressed in $\mathrm{mM}$ eq L-Leucine/g protein with a previously elaboration of a standard curve of $\mathrm{L}$-Leucine (0-2.5 mM).

\section{Antioxidant capacity (AoxC) \\ Abts}

The ability of the peptides to capture the $\mathrm{ABTS}^{+}$radical (2,2'-(azinobis(3-ethyl benzothiazoline-6-sulfonic acid) was evaluated by the method proposed by Re et al. [35]. A solution of $7 \mathrm{mM}$ ABTS was prepared in sodium phosphate buffer $(0.1 \mathrm{M}, \mathrm{pH} 7.4)$ with potassium persulfate $(2.45 \mathrm{mM})$. The reagent was adjusted to an absorbance of 0.8. Thereafter, $1800 \mu \mathrm{L}$ of ABTS solution and $200 \mu \mathrm{L}$ of hydrolysates $(30 \mathrm{mg} / \mathrm{mL})$ were placed and then allowed to stand for $7 \mathrm{~min}$ in the dark. Absorbances were read at $730 \mathrm{~nm}$ in a spectrophotometer. The phosphate buffer was used as a blank and Trolox $(0.6 \mu \mathrm{M})$ as a standard solution. The results were expressed in $\mathrm{mM}$ equivalent to Trolox $(\mathrm{ET}) / \mathrm{mL}$.

\section{Dpph}

The ability to eliminate the DPPH radical (2,2-diphenyl1-picrylhydrazyl) was analyzed according to the methodology described by Park and Chin [36], with certain modifications according to Chou et al. [2]. The solution was obtained by mixing $0.8 \mathrm{~mL}$ of hydrolyzate $(10 \mathrm{mg} /$ $\mathrm{mL}$ ) with $0.2 \mathrm{~mL}$ of $1 \mathrm{mM}$ DPPH (D9132, Sigma Co.) dissolved in $95 \%$ ethanol $(\mathrm{v} / \mathrm{v})$, the mixture was kept in dark for $30 \mathrm{~min}$ at room temperature and then centrifuged at $2000 \times g$ for $5 \mathrm{~min}$ at $4{ }^{\circ} \mathrm{C}$. The absorbance of the supernatant was measured in a SpectraMax M3 microplate reader at $517 \mathrm{~nm}$. Distilled water was used as blank and Trolox $(600 \mu \mathrm{M})$ as a standard solution. The results were expressed in $\mu \mathrm{M} \mathrm{ET/mL}$.

\section{Frap}

The ability of peptides to reduce ferric ion $\left(\mathrm{Fe}^{3+}\right)$ was evaluated by the method of Benzie \& Strain [37]. The FRAP reagent was prepared from $100 \mathrm{~mL}$ of sodium acetate buffer $(300 \mathrm{mM}, \mathrm{pH} 3.6)$ with $10 \mathrm{~mL}$ of TPTZ solution ((2,4,6-tris(2-pyridyl)-s-triazine) in $40 \mathrm{mM} \mathrm{HCl})$ and $10 \mathrm{~mL} \mathrm{FeCl} 3(20 \mathrm{mM})$ and then incubated at $37^{\circ} \mathrm{C}$ for $30 \mathrm{~min}$ in the dark. Next, $100 \mu \mathrm{L}$ of hydrolysates $(30 \mathrm{mg} /$ $\mathrm{mL}$ ) reacted with $1000 \mu \mathrm{L}$ of FRAP reagent, which was incubated at $37{ }^{\circ} \mathrm{C}$ for $30 \mathrm{~min}$ in the dark. The absorbance was read on a spectrophotometer at $595 \mathrm{~nm}$. Distilled water was used as blank and Trolox as standard $(260 \mu \mathrm{M})$. The results were expressed in $\mu \mathrm{M} \mathrm{ET} / \mathrm{mL}$. 
Determination of the peptide profile in the protein hydrolysates

\section{Reversed-phase high-pressure liquid chromatography} (RP-HPLC)

The peptide profile of the hydrolysates $(\mathrm{CH}$ and $\mathrm{FH}$ with BP, BK, and BRO) was measured by RP-HPLC following the methodology of Huang et al. [38], with some modifications. The analysis was performed with a reverse phase HPLC equipment (1100 series; Agilent Technologies Japan Ltd., Tokyo, Japan), the separation was carried out on a Discovery-C18 column $(250 \times 4.6 \mathrm{~mm}, 5 \mu \mathrm{m}$ particle size, 180 - $\AA$ pore size) of Supelco Inc. (Bellefonte, PA) with a solvent flow rate of $0.75 \mathrm{~mL} / \mathrm{min}$ and an injection volume of $30 \mu \mathrm{L}$. Peptides were eluted from a non-isocratic gradient using solvent $\mathrm{B}(0.05 \%$ TFA in acetonitrile) and solvent D (0.05\% TFA in Milli-Q water) for 40 min. $0-30 \mathrm{~min}(100 \% \mathrm{D}), 30-35 \mathrm{~min}(60 \% \mathrm{~B}, 40 \% \mathrm{D})$, $35-40 \mathrm{~min}(100 \% \mathrm{~B}), 40 \mathrm{~min}(100 \% \mathrm{D})$. The peptide profile was monitored at $214 \mathrm{~nm}$.

\section{Size exclusion chromatography (SEC)}

The molecular weight distribution (MW) of the $\mathrm{CH}$ and FH peptides was determined by Size exclusion chromatography (SEC) using a Varian HPLC system equipped with a diode array detector (DAD) (Varian ${ }^{\mathrm{TM}}$ ProStar) and Galaxy $^{\mathrm{TM}}$ software (Varian, version 1.9.302.952) following the methodology used by Román-Gavilanes et al. [39]. 20 $\mu \mathrm{L}$ of the sample was injected at a concentration of $5 \mathrm{mg} /$ $\mathrm{mL}$. The mobile (isocratic) phase consisted of $150 \mathrm{mM}$ phosphate buffer at $\mathrm{pH} 7$ and a flow rate of $0.4 \mathrm{~mL} / \mathrm{min}$. A molecular exclusion column (Agilent BioSEC- $5^{\mathrm{TM}}$ ) of $4.6 \mathrm{~mm}$ internal diameter and $300 \mathrm{~mm}$ in length was used. The absorbance was monitored at $254 \mathrm{~nm}$. The molecular size of the samples was determined based on their retention times using a peptide standard (BIORAD, 151-1901), consisting of thyroglobulin (670 kDa), gamma globulin (158 kDa), ovalbumin (44 kDa), myoglobin (17 kDa), and Vitamin B12 (1.35 kDa).

\section{Statistical analysis}

Statistical analysis of experimental data was performed using a one-way ANOVA. Differences between means were evaluated using the Tukey-Kramer multiple comparison test and were considered significant when $P<0.05$. Statistical analysis was performed using the NCSS 2007 software (NCSS LLC, Kaysville, UT).

\section{Results}

\section{Proteolytic activity}

The specific enzymatic activity of the semi-purified extracts of B. karatas and B. pinguin was $6.24 \pm 0.01 \mathrm{~A}_{\mathrm{U}} /$ $\mathrm{mg}$ and $43.76 \pm 1.60 \mathrm{~A}_{\mathrm{U}} / \mathrm{mg}$, respectively. These results confirmed that the extracted plant proteases are active.

\section{Protein content, yield and degree of hydrolysis of $\mathrm{CH}$ and $\mathrm{FH}$}

In Table 1, we have shown the results of the protein content, yield and degree of hydrolysis of $\mathrm{CH}$ and $\mathrm{FH}$ with enzymes extracted from BP and BK, compared to BRO. The protein content of $\mathrm{FH}$ with $\mathrm{BP}$ and $\mathrm{BK}$ showed no significant differences $(P>0.05)$ with those achieved with $\mathrm{BRO}$, presenting a higher content $(P<0.05)$ compared to those found with $\mathrm{CH}-\mathrm{BP}$ and $\mathrm{CH}-\mathrm{BK}$. Regarding the yield (Table 1), the $\mathrm{CH}$ with $\mathrm{BK}$ and $\mathrm{BRO}$ presented significant differences $(P<0.05)$ with a higher yield $(65.4 \%$ and $65.1 \%$, respectively) than the other hydrolysates.

The degree of hydrolysis (Table 1) of the CH-BP showed the highest value $(P<0.05)$ with $22.9 \%$, which may be related to the high enzymatic activity of BP.

\section{Antioxidant capacity (AoxC) of the protein hydrolysates}

The AoxC of $\mathrm{CH}$ and $\mathrm{FH}$ by means of the ABTS, DPPH and FRAP tests are presented in Fig. 1, where it is observed that the AoxC was affected by the type of substrate (chicken and fish by-products) and the type of plant proteases (BP, BK and BRO). Concerning the ABTS assay, the $\mathrm{CH}$ and $\mathrm{FH}$ with $\mathrm{BK}$ had the

Table 1 Protein content, yield and degree of hydrolysis of by-products hydrolysates

\begin{tabular}{|c|c|c|c|c|}
\hline Hydrolysates & Enzyme & Protein content $(\mathrm{mg} / \mathrm{mL})$ & Yield (\%) & $\begin{array}{l}\text { Degree } \\
\text { of hydrolysis } \\
\text { (\%) }\end{array}$ \\
\hline $\mathrm{CH}$ & $\mathrm{BP}$ & $0.59 \pm 0.04 \mathrm{a}$ & $46.8 \pm 0.4 a$ & $22.9 \pm 1.0 \mathrm{a}$ \\
\hline $\mathrm{FH}$ & & $1.18 \pm 0.37 c$ & $54.3 \pm 1.3 \mathrm{ab}$ & $2.2 \pm 0.4 b$ \\
\hline $\mathrm{CH}$ & BK & $0.79 \pm 0.10 a b$ & $65.4 \pm 4.7 d$ & $8.8 \pm 0.6 c$ \\
\hline $\mathrm{FH}$ & & $1.08 \pm 0.15 b c$ & $49.7 \pm 2.6 \mathrm{ab}$ & $2.2 \pm 0.3 b$ \\
\hline $\mathrm{CH}$ & $\mathrm{BRO}$ & $1.32 \pm 0.12 c$ & $65.1 \pm 5.2 \mathrm{~d}$ & $5.1 \pm 0.3 d$ \\
\hline $\mathrm{FH}$ & & $1.34 \pm 0.16 c$ & $54.8 \pm 1.4 \mathrm{bc}$ & $2.8 \pm 0.6 b$ \\
\hline
\end{tabular}

Protein content, yield (\%), degree of hydrolysis (\%) of chicken by-products hydrolysates (CH) and fish by-products hydrolysates (FH) with enzymes of $B$. pinguin (BP) and $B$. karatas (BK). The means \pm standard deviations $(n=3)$. The different letters mean significant differences (ANOVA, Tukey-Kramer, $P<0.05)$ between treatments 

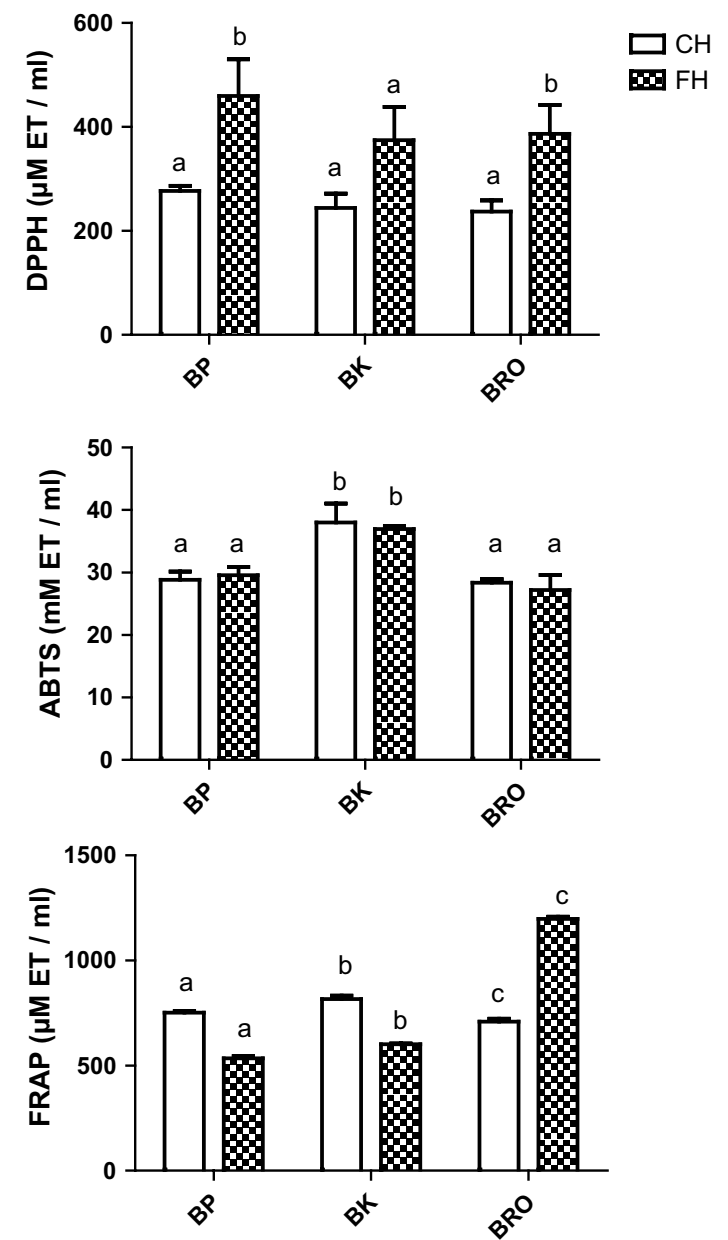

Fig. 1 Antioxidant capacity of chicken by-products hydrolysates and fish by-products Antioxidant capacity by DPPH, ABTS and FRAP of chicken by-products hydrolysates (CH-BP, CH-BK, CH-BRO) and fish by-products (FH-BP, FH-BK, FH-BRO). The different letters mean significant differences (ANOVA, Tukey-Kramer, $P<0.05$ ) between treatments

highest AoxC $(P<0.05)$ with 36.98 and $38.03 \mathrm{mM} \mathrm{ET/}$ $\mathrm{mL}$ respectively. The use of $\mathrm{BP}$ and $\mathrm{BRO}$ generate $\mathrm{CH}$ and $\mathrm{FH}$ with similar AoxC: ABTS $(P<0.05)$. The highest $\mathrm{DPPH}$ radical scavenging activity was obtained for the FH with BP and BRO (483. $21 \mu \mathrm{M} \mathrm{ET} / \mathrm{mL}$ and 454.84 $\mu \mathrm{M} \mathrm{ET} / \mathrm{mL})$. No significant differences $(P<0.05)$ were observed with respect to the AoxC: DPPH of the $\mathrm{CH}$ (BP, BK and $\mathrm{BRO})$. On the other hand, $\mathrm{BRO}$ increased the chelation capacity of ferrous ions only in the $\mathrm{FH}$, presenting the highest AoxC: FRAP values $(P<0.05)$ of $1198.5 \mu \mathrm{M} \mathrm{ET} / \mathrm{mL}$, followed by $\mathrm{CH}-\mathrm{BK}$ with $817.4 \mu \mathrm{M} \mathrm{ET} / \mathrm{mL}$. The use of plant proteases (BP and $\mathrm{BK})$ increased the AoxC: FRAP values $(P<0.05)$ in the $\mathrm{CH}$, showing significant differences $(P<0.05)$ with BRO (Fig. 1).

\section{Profile of peptides from hydrolysates}

Reversed phase-HPLC (RP-HPLC) can be used to separate peptides according to their hydrophobicity. HPLC profiles of the $\mathrm{CH}$ and $\mathrm{FH}$ peptides with $\mathrm{BP}, \mathrm{BK}$ and $\mathrm{BRO}$ are shown in Figs. 2 and 3, respectively.

According to the chromatograms obtained, the use of plant proteases (BP, BK and $\mathrm{BRO}$ ) generates of hydrophilic peptides. Peptides of $\mathrm{CH}$ with BP, BK and BRO started to elute from the column after the first $5 \mathrm{~min}$, which indicates a lower net hydrophobicity and, therefore, a weak binding to the column. Most of the $\mathrm{CH}$ peptides eluted in the first $20 \mathrm{~min}$ when the mobile phase was formed $100 \%$ by Milli-Q water with $0.05 \%$ TFA (Fig. 2). Although, the peptides profile of $\mathrm{CH}$ predominates in hydrophilic peptides, it is also observed that CH-BP (Fig. 2a) generates a few hydrophobic peptides eluted in the $30-35 \mathrm{~min}$.

Regarding the HPLC profiles of the FH with BP, BK and $\mathrm{BRO}$, the peptides show mainly a hydrophilic character, this could be because most of the peptides eluted in the first $20 \mathrm{~min}$ (Fig. 3). FH-BK (Fig. 3b) and FH-BRO (Fig. 3c) present similar profiles, with higher peptide peaks compared to FH-BP (Fig. 3a) in the first $20 \mathrm{~min}$. FH-BP and FH-BRO generates a few hydrophobic peptides eluted in the 30-35 min (Fig. 3).

\section{Distribution of molecular weights (MW) of peptides from hydrolysates}

The SEC process is based on the fractionation of peptides according to the retention time of the molecules in the particles of the stationary phases, in which the molecules separate from each other according to their molecular size [39]. The distribution of the $\mathrm{MW}$ of the $\mathrm{CH}$ and $\mathrm{FH}$ obtained with the proteases of BP and BK, are shown in Figs. 4 and 5.

According to the chromatograms obtained, the MW distribution of the peptides of $\mathrm{CH}$ and $\mathrm{FH}$, is dependent on the plant protease used (BP, BK and BRO). The use of $\mathrm{BRO}$ in $\mathrm{CH}$, showed a higher proportion of low $\mathrm{MW}$ $(<1.35 \mathrm{kDa}$ ) eluted peptides compared to $\mathrm{CH}$ (Fig. 4c), compared to the chromatograms obtained with BP (Fig. 4a) and BK (Fig. 4b), which have a higher elution of peptides of 670-44 kDa. CH-BP and CH-BK have similar peptide profiles of $17-1.35 \mathrm{kDa}$ and $<1.35 \mathrm{kDa}$. Regarding $\mathrm{FH}$, a similar MW distribution is observed with the use of BP (Fig. 5a), BK (Fig. 5b) and BRO (Fig. 5c), according to the chromatograms there is a greater peptide elution low MW $(17-1.35 \mathrm{kDa} ;<1.35 \mathrm{kDa})$.

Respect to the percentage of the area of the chromatograms obtained in the $\mathrm{CH}$, more than $50 \%$ of the peptides has MW below $17 \mathrm{kDa}$ (Table 2). $\mathrm{CH}$ presents higher percentages of peptides $17-1.35 \mathrm{kDa}$ compared to $\mathrm{FH}$. 


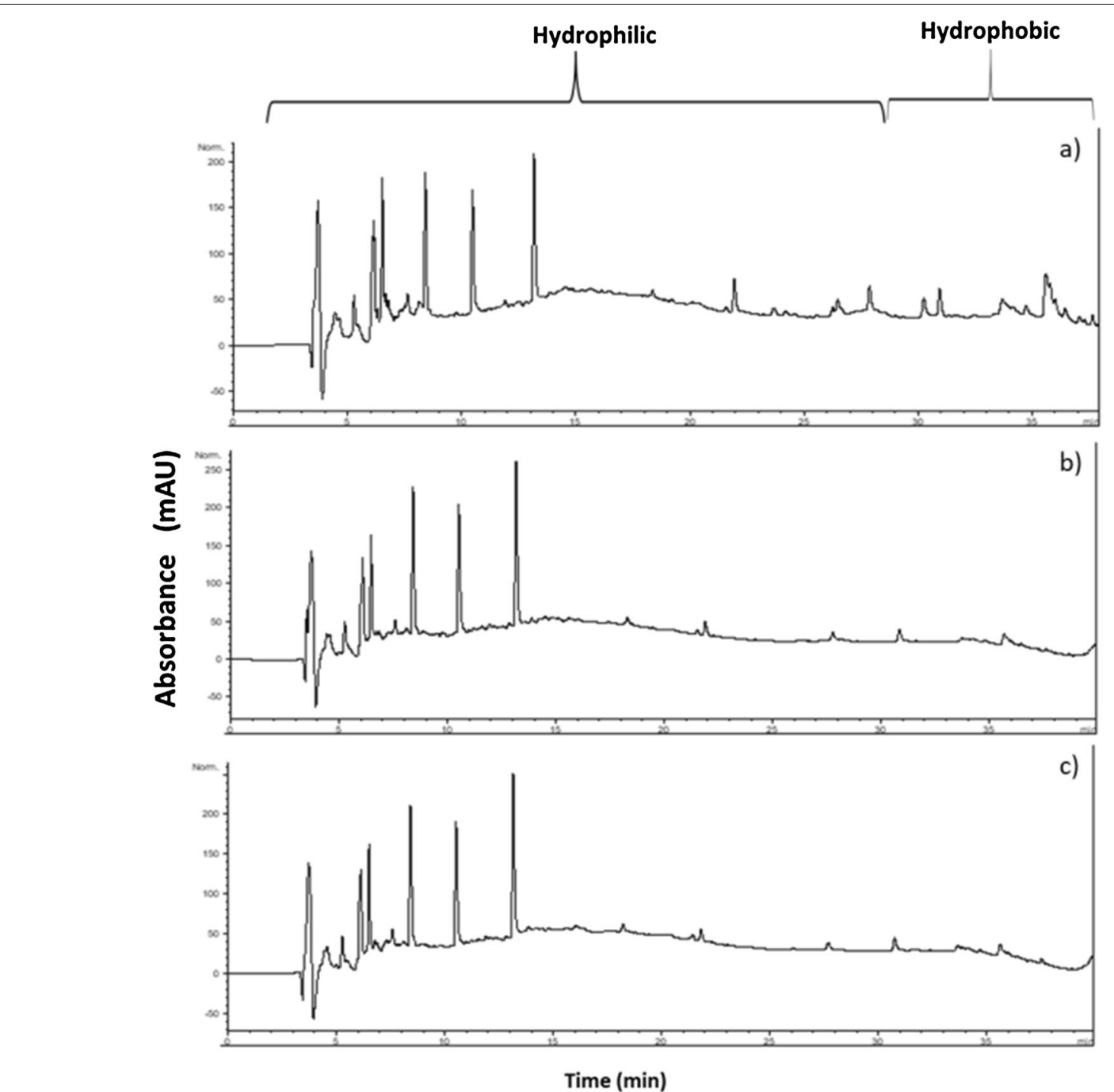

Fig. 2 Peptide fraction profiles of chicken by-products hydrolysates. Peptide fraction profiles corresponding to chicken by-products hydrolysates $(\mathrm{CH})$ by BP (a), BK (b) and BRO (c) using reversed-phase HPLC at $214 \mathrm{~nm}$

$\mathrm{CH}-\mathrm{BP}(24.4 \%)$ and $\mathrm{CH}-\mathrm{BK}(22.5 \%)$ have similar content of peptides $<1.35 \mathrm{kDa}$. Regarding the $\mathrm{FH}$, the percentage of peptides $<1.35 \mathrm{kDa}$ increases, compared with $\mathrm{CH}$ (Table 2). FH-BP presents the highest percentage of peptides of $<1.35 \mathrm{kDa}(51.3 \%)$, followed by FH-BRO (48.9\%) and $\mathrm{FH}-\mathrm{BK}$ (46.9\%).

\section{Discussion}

The fruits of B. karatas and B. pinguin have been characterized as promising sources of plant proteases $[25,28-30,40]$. One of the important points of this research is the incorporation of these plant enzymes in food technology processes and the obtaining of protein hydrolysates from food by-products and their comparison with a commercial plant enzyme (bromelain). The use of enzymes for the production of hydrolysates has been the subject of research for years [41]. The enzymes extracted from BP and BK show differences between their enzymatic activities, which coincide with what was previously reported by GarcíaMagaña et al. [30] $(5.08 \pm 0.70$ for BK proteases and $43.58 \pm 0.40$ for BP proteases). BP proteases showed higher activity compared to BK proteases, this behavior is similar to the already reported by Aguilera-Aguirre et al. [40] and Meza-Espinoza et al. [25], and can be attributed to the presence of different types of cysteine proteases in both fruits [26, 30, 42]. In the same way, it has been reported that the different genetic 

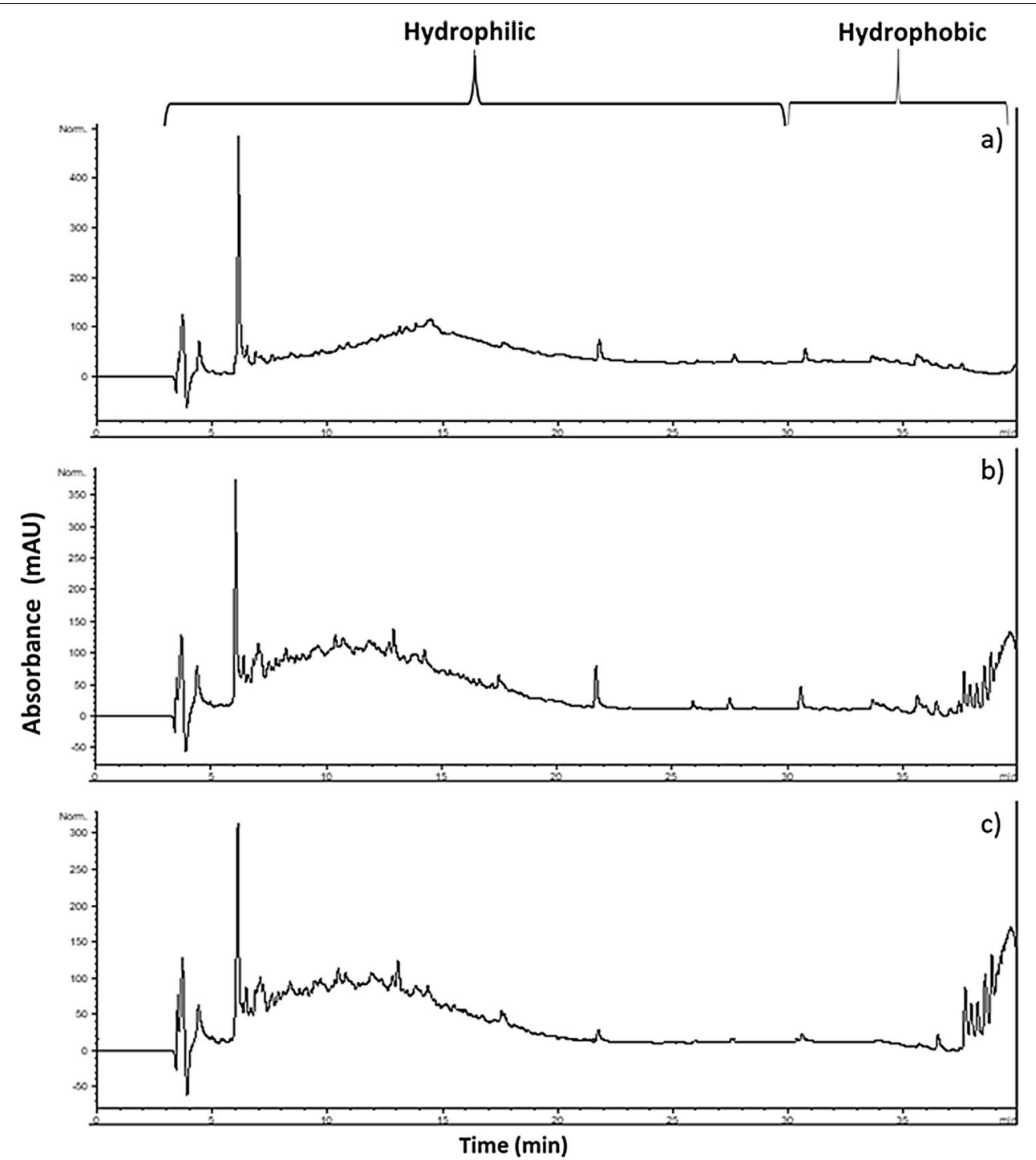

Fig. 3 Peptide fraction profiles of fish by-products hydrolysates. Peptide fraction profiles corresponding to fish by-products hydrolysates (FH) with $\mathrm{BP}(\mathbf{a}), \mathrm{BK}(\mathbf{b})$ and BRO (c) using by reversed-phase HPLC at $214 \mathrm{~nm}$

characteristics of each fruit species synthesize endopeptidases with different structures and catalytic activities [25].

The application of BP and BK proteases in the hydrolysis of chicken by-products and fish by-products gave us variable results to their protein content, yield and degree of hydrolysis. Among the different biochemical parameters, the degree of hydrolysis is one of the most important characteristics, since it directly influences the length of the peptide, its nutritional and functional properties, as well as it is directly related to their solubility and digestibility [41]. Meza-Espinoza et al. [31] reported that BP proteases generate a greater degree of hydrolysis in different protein sources (milk, soy protein, and egg ovalbumin) compared to BK. Few references regarding the use of plant proteases to obtain hydrolysates from animal by-products can be found. It has been reported that the use of papain to hydrolyze by-products of bovine origin showed $6 \%$ of DH [43]. Likewise, the use of papain (EC 3.4.22.2) and bromelain (EC 3.4.22.32) with DH of $15 \%$ for obtaining hydrolysates of fish by-products with bioactive and functional properties [17].

The yield depends on the nature of the proteases used, the amount of proteins present in the substrate, the hydrolysis conditions, the concentration of the proteases and the hydrolysis time $[4,17]$. According to the results obtained, we observed a greater affinity of the proteases of $\mathrm{BP}, \mathrm{BK}$ and $\mathrm{BRO}$ to hydrolyze chicken by-product 


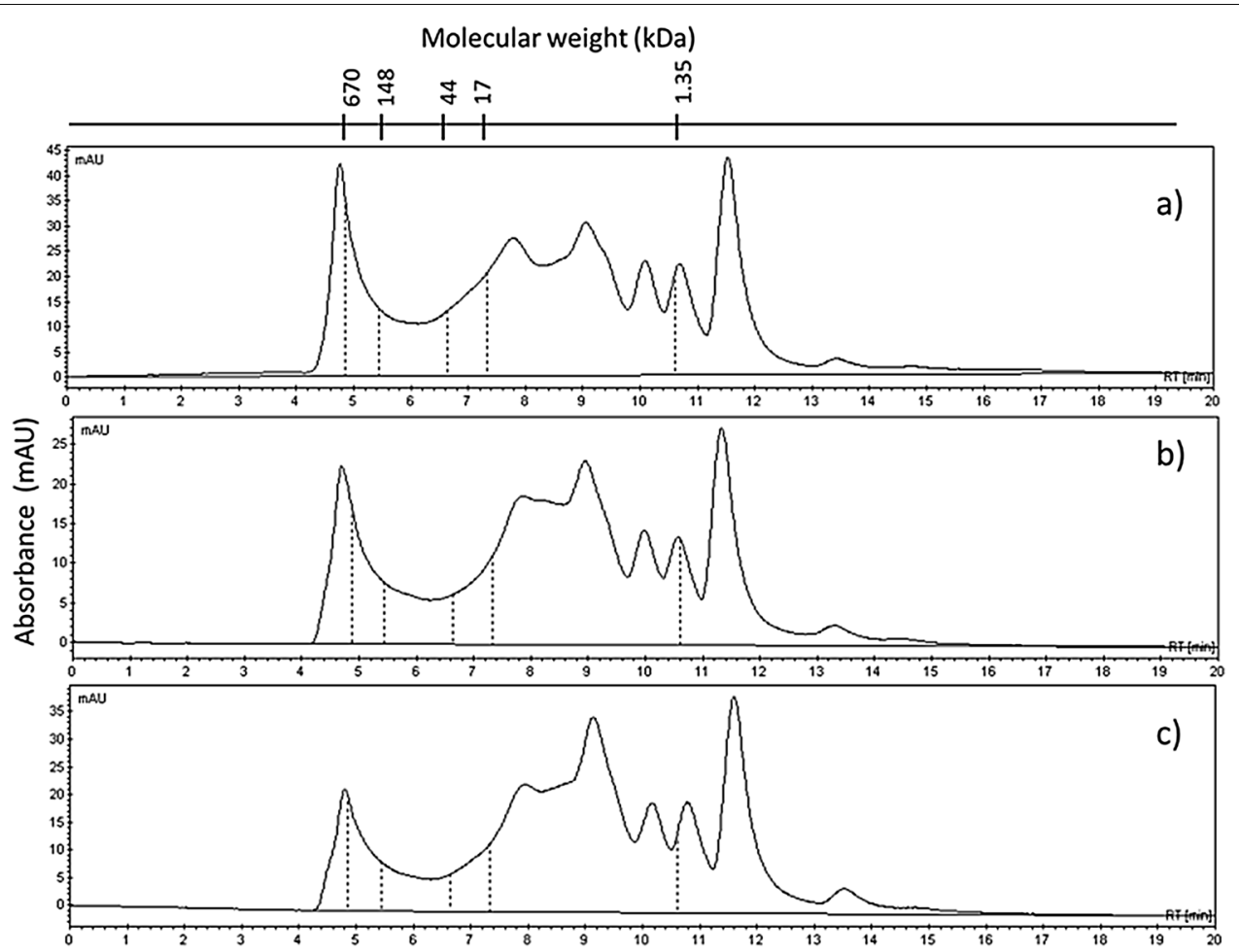

Fig. 4 Chromatographic profiles of chicken by-products hydrolysates. Chromatographic profiles of chicken by-products hydrolysates (CH) with BP (a) and BK (b) proteases and BRO (c). The graph shows the signal from the UV monitor at $254 \mathrm{~nm}$

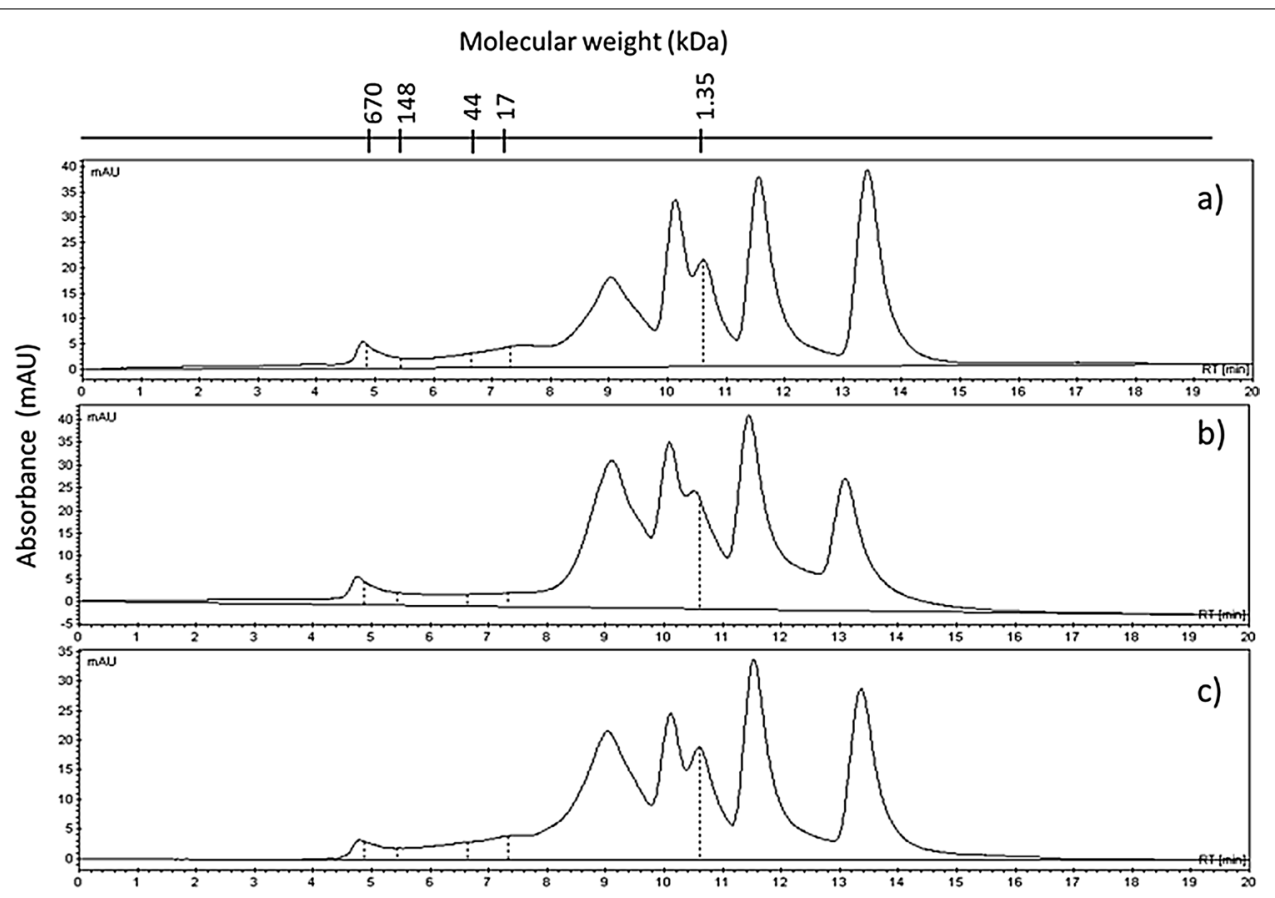

Fig. 5 Chromatographic profiles of fish by-products hydrolysates. Chromatographic profiles of fish by-products hydrolysates (FH) with BP (a) and BK (b) proteases and BRO (c). The graph shows the signal from the UV monitor at $254 \mathrm{~nm}$ 
Table 2 Chromatographic profiles of peptides of by-products hydrolysates

\begin{tabular}{|c|c|c|c|c|c|c|}
\hline \multirow[t]{2}{*}{ Molecular weight (kDa) } & \multicolumn{3}{|c|}{$\mathrm{CH}(\%)$} & \multicolumn{3}{|c|}{ FH (\%) } \\
\hline & BP & BK & BRO & BP & BK & BRO \\
\hline$>670$ & 8.3 & 8.2 & 4.6 & 3.3 & 3.5 & 1.0 \\
\hline $670-148$ & 7.5 & 6.2 & 5.8 & 1.7 & 1.6 & 1.4 \\
\hline $148-44$ & 8.3 & 7.3 & 5.9 & 2.5 & 2.3 & 3.0 \\
\hline $44-17$ & 7.0 & 5.6 & 4.7 & 2.3 & 1.5 & 2.5 \\
\hline $17-1.35$ & 44.6 & 50.2 & 51.1 & 38.8 & 44.3 & 43.2 \\
\hline$<1.35$ & 24.4 & 22.5 & 27.9 & 51.3 & 46.9 & 48.9 \\
\hline
\end{tabular}

Chromatographic profiles of peptides corresponding to chicken by-products hydrolysates $(\mathrm{CH})$ and fish by-products hydrolysates $(\mathrm{FH})$ obtained with BP protease, BK protease, and BRO

proteins compared to fish by-products presenting significant differences $(P<0.05)$ and resulting in the $\mathrm{CH}$ obtained a higher yield and DH compared to the $\mathrm{FH}$.

A degree of hydrolysis greater than $10 \%$ generates peptides that have high solubility and superior bioavailability. On the other hand, a low degree of hydrolysis (1-10\%) improves the functional properties of food products such as foaming power and emulsifier [41].

The biological effect of peptides isolated from by-products derived from the meat industry has been studied in vitro for their antihypertensive and antioxidant activity, which provides a basis for their use as bioactive peptides [5], and their activity is mainly related to structure and nature of the AA that conformed. An example is its AoxC, which is mainly attributed to the presence of aromatic AA (tyrosine, tryptophan, and phenylalanine) in its terminal chains, since they have the ability to efficiently neutralize free radicals, acting as electron donors/hydrogen due to the presence of phenolic, indole and imidazole groups; in the same way, they can reduce $\mathrm{Fe}^{3+}$ ions to $\mathrm{Fe}^{2+}$ and chelate $\mathrm{Fe}^{2+}$ as well as $\mathrm{Cu}^{2+}$ ions [43, 44]. It has been reported that the ferric ion (FRAP) can be oxidized by hydrophilic compounds, just like the ABTS radical [45]; although it has also been reported that ABTS may be neutralized by some compounds, poorly soluble or lipophilic [46]; while DPPH detects hydrophilic compounds in greater presence [47]. Therefore, the results of AoxC are directly related to the characteristics of hydrolysates/peptides derived from chicken and fish by-products; as well as the biochemical and structural characteristics that each one of the hydrolysates present when using different types of plant proteases (BP, BK and $\mathrm{BRO}$ ). According to the specificity of each protease, they can produce hydrolysates with different sizes of peptides, AA composition and their location in the side chains [40], which provides their characteristics about their polarity (polar or non-polar) and solubility (hydrophobic and hydrophilic) as well as its possible mechanisms of action. From the results, it is evident that the $\mathrm{CH}$ and $\mathrm{FH}$ obtained with the plant enzymes extracted from BP and $\mathrm{BK}$ are equal or more efficient than $\mathrm{BRO}$ for obtaining hydrolysates with AoxC.

In the peptide profile presented in this study (RPHPLC), a higher percentage of hydrophilic peptides with different polarity index is observed, which suggests the presence of hydrophilic AA (Asp, Glu, Pro, Lys, Asn, and Arg) and neutral nature (His, Gly, Gln, Ser and Thr) in the C-terminal position. Of this AA, His, Lys and Arg are categorized in the AA group with strong AoxC together with hydrophobic AAs such as Met, Trp, and Tyr according to a study where they categorized 20 AA in relation to their AoxC [48]. Likewise, it has been suggested that a close relationship exists between polar peptides and the type of amino acid positioned in their side chains [49]. AA sequences of peptides derived from animal byproducts having polar character AA in their side chains derived from poultry by-products with antioxidant capacity (Ser-Asn-Leu-Cys-Arg-Pro-Cys-Gly) [1], antihypertensive character (Cys-Gly-Lys-Pro, Ser-Gly-Arg, Cys-Thr-Ser-His, Val-Lys-Lys-Tyr) [50] and (Ala-Arg-IleTyr -His, Leu-Arg-Lys-Gly-Asn-Leu-Glu) [51] as well as by-products of marine origin with antioxidant capacity (Trp-Glu-Gly-ProLys; Gly-Pro-Pro; Gly-Val- Pro-LeuThr) have been determined [52].

Peptides with $\mathrm{MW}<10 \mathrm{kDa}$ are considered bioactive which can generate multiple biological activities, thus the interest of incorporating these compounds in the food area, as well as in the pharmaceutical industry. Chicken liver hydrolysates with pepsin showed MW between 4.6 and $10 \mathrm{kDa}$ [2], which have been shown to have multifunctional effects on in vivo systems with murine models induced to liver damage favoring (1) the regulation of lipid homeostasis, (2) decrease in lipid peroxidation through the improvement of antioxidant enzyme activities (3) improvement of gene expression related to the pathologies evaluated and (4) decrease in hepatic inflammatory responses $[15,53]$. Based on the results obtained, the application of $\mathrm{BP}$ and $\mathrm{BK}$ proteases in chicken and 


\section{fish by-products are useful for obtaining low MW pep- tides $(17.5-1.35 \mathrm{kDa})$.}

\section{Acknowledgements}

The authors thank CONACYT-Mexico for the scholarship granted (number 287441). This work is part of the activities of the RED TEMATICA CONACYT 12.3, to Reduce and Valorize Food Losses and Waste. Towards Sustainable Food Systems (294768).

\section{Authors' contributions}

MGRG Produced the data and drafted the original manuscript. EMM provided the equipment for the determination of exclusion molecular, analyzed and interpreted the data of size exclusion chromatography (SEC). AHM, BVC and AFGC provided the equipment for the determination of peptide profile in the protein hydrolysates and they analysed the data of peptide profile. EMG analysed data formally, supervised and revised the work substantially. MLGM formally analysed data in general, supervised, revised the work substantially and acquisition of resources for research development. All authors read and approved the final manuscript.

\section{Funding}

This research was funded by Tecnológico Nacional de México (project code 5565.19-P)

\section{Availability of data and materials}

The datasets used and/or analysed during the current study are available from the corresponding author on reasonable request. All data analysed during this study are included in this article.

\section{Competing interests}

The authors declare that they have no competing interests.

\section{Author details}

${ }^{1}$ Laboratorio Integral de Investigación en Alimentos, Tecnológico Nacional de México/Instituto Tecnológico de Tepic, Av. Tecnológico 2595, Col. Lagos del Country, 63175 Tepic, Nayarit, Mexico. ${ }^{2}$ Maestría en Ciencias Aplicadas. Unidad Académica de Ingeniería en Biotecnología, Universidad Politécnica de Sinaloa, Mazatlán, Sinaloa, Mexico. ${ }^{3}$ Cátedras CONACYT, Consejo Nacional de Ciencia y Tecnología, Ciudad de México, Mexico. ${ }^{4}$ Laboratorio de Química y Biotecnología de Productos Lácteos Centro de Investigación en Alimentación y Desarrollo A.C. (CIAD), Carretera a La Victoria Km. 0.6, 83304 Hermosillo, Sonora, Mexico.

Received: 25 March 2020 Accepted: 15 July 2020

Published online: 22 July 2020

\section{References}

1. Wan MY, Dong G, Yang BQ, Feng H (2016) Identification and characterization of a novel antioxidant peptide from feather keratin hydrolysate. Biotechnol Lett 38:643-649. https://doi.org/10.1007/s10529-015-2016-9

2. Chou CH, Wang SY, LiNYT, Chen YC (2014) Antioxidant activities of chicken liver hydrolysates by pepsin treatment. Int J Food Sci Technol 49:1654-1662. https://doi.org/10.1111/ijfs. 12471

3. Lee SJ, Kim YS, Hwang JW, Kim EK, Moon SH, Jeon BT, Jeon YJ, Kim JM, Park PJ (2012) Purification and characterization of a novel antioxidative peptide from duck skin by-products that protects liver against oxidative damage. Food Res Int 49:285-295. https://doi.org/10.1016/j.foodr es.2012.08.017

4. Mazorra-Manzano MA, Ramírez-Suarez JC, Yada RY (2017) Plant proteases for bioactive peptides release: a review. Crit Rev Food Sci. https://doi. org/10.1080/10408398.2017.1308312

5. Xing L, Liu R, Cao S, Zhang W, Guanghong Z (2019) Meat protein based bioactive peptides and their potential functional activity: a review. Int J Food Sci Technol 54:1956-1966. https://doi.org/10.1111/ijfs.14132

6. Daliri E, Oh D, Lee B (2017) Bioactive peptides. Foods 6:32. https://doi. org/10.3390/foods6050032
7. Lasekan A, Abu Bakar F, Hashim D (2013) Potential of chicken by-products as sources of useful biological resources. J Waste Manag 33:552-565. https://doi.org/10.1016/j.wasman.2012.08.001

8. Sánchez A, Vázquez A (2017) Bioactive peptides: a review. FQS 1:29-46. https://doi.org/10.1093/fas/fyx006

9. Lafarga T, Álvarez C, Hayes M (2017) Bioactive peptides derived from bovine and porcine co-products: a review. J Food Biochem 41:1-18. https ://doi.org/10.1111/jfbc.12418

10. Sila A, Bougatef A (2016) Antioxidant peptides from marine by-products: isolation, identification and application in food systems. A review. J Funct Foods 21:10-26. https://doi.org/10.1016/j.jff.2015.11.007

11. Liu R, Xing L, Fu Q, Zhou G, Zhang WA (2016) Review of antioxidant peptides derived from meat muscle and by-products. Antioxidants 5:32. https://doi.org/10.3390/antiox5030032

12. Lafarga T, Hayes MV (2014) Bioactive peptides from meat muscle and byproducts: generation, functionality and application as functional ingredients. Meat Sci 98:227-239. https://doi.org/10.1016/j.meatsci.2014.05.036

13. Toldrá F, Mora L, Reig M (2016) New insights into meat by-product utilization. Meat Sci 20:54-59. https://doi.org/10.1016/j.meatsci.2016.04.021

14. Chakka AK, Elias M, Jini R, Sakhare PZ, Bhaskar N (2015) In-vitro antioxidant and antibacterial properties of fermentatively and enzymatically prepared chicken liver protein hydrolysates. J Food Sci Technol 52:8059-8067. https://doi.org/10.1016/j.meatsci.2016.04.021

15. Lin YL, Tai SY, Chen JW, Chou CH, Fu SG, Chen YC (2017) Ameliorative effects of pepsin-digested chicken liver hydrolysates on development of alcoholic fatty livers in mice. Food Funct 8:1763-1774. https://doi. org/10.1039/C7FO00123A

16. Lee SJ, Cheong SH, Kim YS, Hwang JW, Kwon HJ, Kang SH, Moon SH, Jeon BT, Park PJ (2013) Antioxidant activity of a novel synthetic hexa-peptide derived from an enzymatic hydrolysate of duck skin by-products. Food Chem Toxicol 62:276-280. https://doi.org/10.1016/j.fct.2013.08.054

17. Gajanan PG, Elavarasan K, Shamasundar BA (2016) Bioactive and functional properties of protein hydrolysates from fish frame processing waste using plant proteases. Environ Sci Pollut 23:24901-24911. https:// doi.org/10.1007/s11356-016-7618-9

18. Soladoye OP (2014) Antioxidant and angiotensin 1 converting enzyme inhibitory functions from chicken collagen hydrolysates. J Nutr Food Sci 05:1-10. https://doi.org/10.4172/2155-9600.1000369

19. Sudhakar S, Nazeer RA (2015) Structural characterization of an Indian squid antioxidant peptide and its protective effect against cellular reactive oxygen species. J Funct Foods 14:502-512. https://doi.org/10.1016/j. jff.2015.02.028

20. Girgih AT, He R, Hasan FM, Udenigwe CC, Gill TA, Aluko RE (2015) Evaluation of the in vitro antioxidant properties of a cod (Gadus morhua) protein hydrolysate and peptide fractions. Food Chem 173:652-665. https:// doi.org/10.1016/j.foodchem.2014.10.079

21. Ahn CB, Cho YS, Je JY (2015) Purification and anti-inflammatory action of tripeptide from salmon pectoral fin byproduct protein hydrolysate. Food Chem 168:151-156. https://doi.org/10.1016/j.foodchem.2014.05.112

22. Cai L, Wu X, Zhang Y, Li X, Ma S, Li J (2015) Purification and characterization of three antioxidant peptides from protein hydrolysate of grass carp (Ctenopharyngodon idella) skin. J Funct Foods 16:234-242. https://doi. org/10.1016/j.jff.2015.04.042

23. Bah CSF, Carne A, McConnell MA, Mros S, Bekhit AEDA (2016) Production of bioactive peptide hydrolysates from deer, sheep, pig and cattle red blood cell fractions using plant and fungal protease preparations. Food Chem 202:458-466. https://doi.org/10.1016/j.foodchem.2016.02.020

24. Di Bernardini R, Mullen AM, Bolton D, Kerry J, O’Neill E, Hayes M (2012) Assessment of the angiotensin-I-converting enzyme (ACE-I) inhibitory and antioxidant activities of hydrolysates of bovine brisket sarcoplasmic proteins produced by papain and characterisation of associated bioactive peptidic fractions. Meat Sci 90:226-235. https://doi.org/10.1016/j.meats ci.2011.07.008

25. Meza-Espinoza L, de los Ángeles Vivar-Vera M, de Lourdes GarcíaMagaña M, Sáyago-Ayerdi SG, Chacón-López A, Becerrea-Verdín EM, Montalvo-González E (2018) Enzyme activity and partial characterization of proteases obtained from Bromelia karatas fruit and compared with Bromelia pinguin proteases. Food Sci Biotechnol 27:509-517. https://doi. org/10.1007/s10068-017-0244-6

26. Moreno-Hernández JM, Hernández-Mancillas XD, Navarrete ELC, MazorraManzano MÁ, Osuna-Ruiz I, Rodríguez-Tirado VA, Salazar-Leyva JA (2017) 
Partial characterization of the proteolytic properties of an enzymatic extract from "Aguama" Bromelia pinguin L. fruit grown in Mexico. Appl Biochem Biotechnol 182:181-196. https://doi.org/10.1007/s1201 $0-016-2319-x$

27. de Villanueva-Alonzo H J, Polanco-Hernández GM, Lizama-Uc G, AcostaViana KY, Alvarado-Segura AA (2019) Proteolytic activity of wild fruits of Bromelia karatas L. of Yucatán, Mexico. Revista Chapingo Serie Ciencias Forestales y del Ambiente 25:157-168. https://doi.org/10.5154/r.rchsc fa.2018.08.062

28. Meza-Espinoza L, García-Magaña MDL, Vivar-Vera MDLA, Sáyago-Ayerdi SG, Chacón-López A, Becerra-Verdín EM, Muy-Rangel D, MontalvoGonzález E (2017) Ethnobotanical and nutritional aspects, and biological activity of fruit extracts of the genus Bromelia. Rev Fitotec Mex 40:425-437

29. Meza-Espinoza L, Sáyago-Ayerdi SG, de García-Magaña M L, Tovar-Pérez EG, Yahia EM, Vallejo-Cordoba B, González-Córdova AF, HernándezMendoza A, Montalvo-González E (2018) Antioxidant capacity of egg, milk and soy protein hydrolysates and biopeptides produced by Bromelia pinguin and Bromelia karatas-derived proteases. Emir J Food Agric 30:122-130. https://doi.org/10.9755/ejfa.2018.v30.i2.1604

30. de García-Magaña M L, González-Borrayo J, Montalvo-González E, Rudiño-Piñera E, Sáyago-Ayerdi SG, Salazar-Leyva JA (2018) Isoelectric focusing, effect of reducing agents and inhibitors: partial characterization of proteases extracted from Bromelia karatas. Appl Biol Chem 61:459-467. https://doi.org/10.1007/s13765-018-0380-6

31. Natalucci CL, Brullo A, López LMI, Hilal RM, Caffini NO (1995) Macrodontin, a new protease isolated from fruits of Pseudananas macrodontes (Morr.) Harms (Bromeliaceae). J Food Biochem 19:443-445. https://doi. org/10.1111/j.1745-4514.1995.tb00547.x

32. Bradford MM (1976) A rapid and sensitive method for the quantitation of microgram quantities of protein utilizing the principle of protein-dye binding. Anal Biochem 72:248-254. https://doi.org/10.1016/00032697(76)90527-3

33. Adler-Nissen J (1979) Determination of the degree of hydrolysis of food protein hydrolysates by trinitrobenzenesulfonic acid. J Agric Food Chem 27:1256-1262. https://doi.org/10.1021/jf60226a042

34. Tovar-Pérez EG, Guerrero-Legarreta I, Farrés-González A, Soriano-Santos $J$ (2009) Angiotensin I-converting enzyme-inhibitory peptide fractions from albumin 1 and globulin as obtained of amaranth grain. Food Chem 116:437-444. https://doi.org/10.1016/j.foodchem.2009.02.062

35. Re R, Pellegrini N, Proteggente A, Pannala A, Yang M, Rice-Evans C (1999) Antioxidant activity applying an improved ABTS radical cation decolorization assay. Free Radic Biol Med 26:1231-1237. https://doi.org/10.1016/ S0891-5849(98)00315-3

36. Park SY, Chin KB (2011) Antioxidant activities of pepsin hydrolysates of water-and salt-soluble protein extracted from pork hams. Int J Food Sci Technol 46:229-235. https://doi.org/10.1111/j.1365-2621.2010.02454.x

37. Benzie IFF, Strain JJ (1996) The ferric reducing ability of plasma (FRAP) as a measure of "antioxidant power": the FRAP assay. Anal Biochem 239:70-76. https://doi.org/10.1006/abio.1996.0292

38. Huang J, Liu Q, Xue B, Chen L, Wang Y, Ou S, Peng X (2016) AngiotensinI-converting enzyme inhibitory activities and in vivo antihypertensive effects of sardine protein hydrolysate. J Food Sci 81:H2831-H2840. https ://doi.org/10.1111/1750-3841.13508

39. Román-Gavilanes Al, Martínez-Montaño E, Viana MT (2015) Comparative characterization of enzymatic digestion from fish and soybean meal from simulated digestive process of Pacific Bluefin Tuna, Thunnus orientalis. J World Aquacult Soc 46:409-420. https://doi.org/10.1111/jwas.12204

40. Aguilera-Aguirre S, Meza-Espinoza L, Hernández-Mendoza A, VallejoCórdoba B, González-Córdova AF, Montalvo-González E (2018) Evaluación de la capacidad de inhibición de hemólisis oxidativa y actividad antimicrobiana de fracciones peptídicas obtenidas de la hidrólisis de proteínas de huevo, leche y soya usando proteasas extraídas de Bromelia pinguin y Bromelia karatas. TIP Revista Especializada en Ciencias Químico-Biológicas 21:13-21. https://doi.org/10.22201/fesz.23958723e.2019.1.142

41. Hleap J, Gutiérrez C (2017) Hidrolizados de pescado - producción, beneficios y nuevos avances en la industria. -Una revisión review. Acta Agronómica 66:311-322

42. Abreu-Payrol J, Walter PA, Ne ATE (2008) Purification and characterization of four new cysteine endopeptidases from fruits of Bromelia pinguin $\mathrm{L}$. grown in Cuba. Protein J. https://doi.org/10.1007/s10930-007-9111-2

43. Duan X, Ocen D, Wu F, Li M, Yang N, Xu J, Chen H, Huang L, Jin Z, Xu X (2014) Purification and characterization of a natural antioxidant peptide from fertilized eggs. Food Res Int 56:18-24. https://doi.org/10.1016/j. foodres.2013.12.016

44. Zheng L, Zhao Y, Dong H, Su G, Zhao M (2016) Structure-activity relationship of antioxidant dipeptides: dominant role of Tyr, Trp, Cys and Met residues. J Funct Foods 21:485-496. https://doi.org/10.1016/j.jff.2015.12.003

45. Wu X, Beecher GR, Holden JM, Haytowitz DB, Gebhardt SE, Prior RL (2004) Lipophilic and hydrophilic antioxidant capacities of common foods in the United States. J Agric Food Chem 52:4026-4037. https://doi.org/10.1021/ jf049696w

46. Gordillo JC, Ortiz D, Larrahondo JE, Mejia MS, Pachon H (2012) Actividad antioxidante en guanábana (Annona muricata L.): una revisión bibliográfica. Boletin latinoamericano y del caribe de plantas medicinales y aromáticas 11:111-126

47. Foti MC, Daquino C, Geraci C (2004) Electron-transfer reaction of cinnamic acids and their methyl esters with the DPPH. radical in alcoholic solutions. J Org Chem 69:2309-2314. https://doi.org/10.1021/jo035758q

48. Xu N, Chen G, Liu H (2017) Antioxidative categorization of twenty amino acids based on experimental evaluation. Molecules 22(12):2066. https:// doi.org/10.3390/molecules22122066

49. Rodríguez-Figueroa JC, González-Córdova AF, Torres-Llanez MJ, Garcia HS, Vallejo-Cordoba B (2012) Novel angiotensin I-converting enzyme inhibitory peptides produced in fermented milk by specific wild Lactococcus lactis strains. J Dairy Sci 95:5536-5543. https://doi.org/10.3168/ jds.2011-5186

50. Onuh JO, Girgih AT, Nwachukwu I, levari-Shariati S, Raj P, Netticadan T, Aluko RE, Aliani MA (2016) Metabolomics approach for investigating urinary and plasma changes in spontaneously hypertensive rats (SHR) fed with chicken skin protein hydrolysates diets. J Funct Foods 22:20-23. https://doi.org/10.1016/j.jff.2016.01.010

51. Mane S, Jamdar SN (2017) Purification and identification of Ace-inhibitory peptides from poultry viscera protein hydrolysate. J Food Biochem 41:1-10. https://doi.org/10.1111/jfbc.12275

52. Chi CF, Wang B, Wang YM, Zhang B, Deng SG (2015) Isolation and characterization of three antioxidant peptides from protein hydrolysate of bluefin leatherjacket (Navodon septentrionalis) heads. J Funct Foods 12:1-10. https://doi.org/10.1016/j.jff.2014.10.027

53. Chen PJ, Tseng JK, Lin YL, WU YHS, Hsiao YT, Chen JW, Chen YC (2017) Protective effects of functional chicken liver hydrolysates against liver fibrogenesis: antioxidation, anti-inflammation, and antifibrosis. J Agric Food Chem 65:4961-4969. https://doi.org/10.1021/acs.jafc.7b01403

\section{Publisher's Note}

Springer Nature remains neutral with regard to jurisdictional claims in published maps and institutional affiliations. 